\title{
Veduta dell'Anfiteatro Flavio detto il Colosseo Giovanniego Battisty Piranesiego
}

Abstrakt: W artykule poddano analizie rycinę Veduta dell'Anfiteatro Flavio detto il Colosseo Giovanniego Battisty Piranesiego w kontekście badań nad „miejscami pamięci”, których prekursorem był Pierre Nora. Dzieło artystyczne jest wytworem materialnym, jednocześnie zawiera w sobie ideę i odnosi się do świata wartości. Pozwala to odbiorcy przejść w procesie jego percepcji od poziomu realnego do metafizycznego.

Słowa kluczowe: Rzym, Koloseum, przeszłość, „miejsca pamięci”, Giovanni Battista Piranesi, rycina, idea, wartości

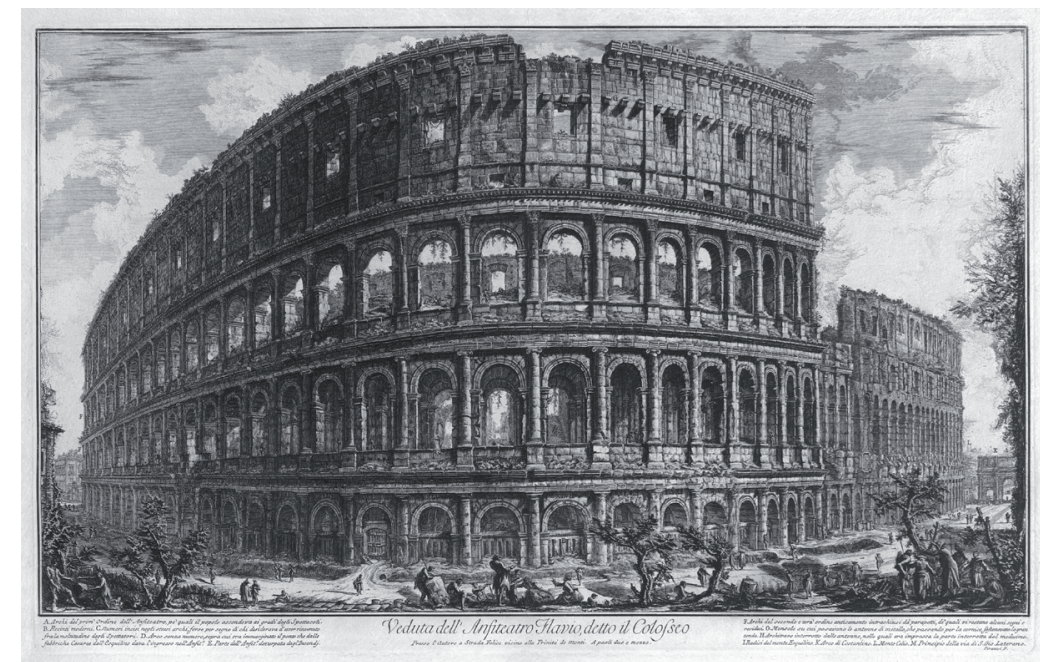

Fot. 1. Giovanni Battista Piranesi, The Colosseum, 1757, rycina, domena publiczna, https:// en.wikipedia.org/wiki/File:Giovanni_Battista_Piranesi,_The_Colosseum.png (dostęp: 1.01.2021); fot. R.S. Johnson fine art 
Giovanni Battista Piranesi, włoski architekt i rytownik, przemierzał drogi Wiecznego Miasta, aby wsłuchiwać się w głosy przeszłości i zgłębiać ich tajemnice. Jak twierdził, u źródła widać lepiej i dokładniej, tam objawia się prawda. Tej poszukiwał w dawnych tekstach, wierząc, że uda mu się wrócić do miejsca, w którym ukazała się w pełnym blasku.

Martin Heidegger w książce Bycie i czas dowodził, że pytanie o źródło wymaga skoku w głąb, „nie ma nic wspólnego z przyjmowaniem jakiegoś aksjomatu, z którego dedukcyjnie wywodziłby się ciąg twierdzeń. »Błędne koło w dowodzie« nie może w ogóle mieć miejsca przy stawianiu pytania o sens bycia, gdyż w odpowiedzi na to pytanie nie chodzi o uzasadnienie czegoś przez wywód, lecz o odsłonięcie podstawy i ukazanie jej”' „Źródło” (niem. Ursprung) oznacza zwrot ku przeszłości, skok przez wszystkie czasy do pierwotnej idei, myśli i wiary. W interesujący sposób Edmund Husserl pisał o źródle jako prafenomenie duchowej Europy, czyli źródło to cała europejska kultura² ${ }^{2}$ Źródłowość jest nie tyle przyczyną, ile wydarzeniem, które ujawnia sens biegu wszystkich następnych spraw, historii, poznania, poszukującej myśli. Wojciech Karpiński w książce Pamięć Włoch napisał o Giovannim Piranesim:

Rzym zafascynował go pomnikami przeszłości, a były to czasy, gdy wiedza o tych zabytkach dopiero się rodziła. Piranesi należy do najbardziej zasłużonych badaczy starożytności rzymskich. Godzinami błąkał się po opuszczonych ruinach, po ulicach, zaułkach. Chciał poznać każde oświetlenie, każdy punkt widzenia. Zdobył już u współczesnych sławę wielkiego artysty; stał się europejską znakomitością. Był dla wielu przewodnikiem po Rzymie. Kiedy w dalekich krajach oglądali jego ryciny, byli olśnieni ich wspaniałością i na ich podstawie formowali swój obraz starożytnościª

Źródło to kategoria ściśle związana z czasem. M. Heidegger czas rozważał w perspektywie ontologiczno-metafizycznej, wskazując, że źródło czasu znajduje się w samej istocie bycia. Inspiracją dla niemieckiego filozofa były teorie Platona i Plotyna, w szczególności dzieło Timaios, w którym Platon napisał, że czas to „ruchomy obraz wieczności”4. W definicji tej jest obecne napięcie między tym, co wieczne i niezmienne, a więc co trwa, a tym, co zmienne, czyli czasowe. Czas wypełnia brak i powoduje ruch. Jest to ruch, którego istota polega na dążeniu bytu do doskonalenia się i otwarcia na inne. Czas nie jest więc czymś zewnętrznym wobec duszy, jest wewnątrz stworzonego przez nią świata, a zatem i w każdym z nas. Droga do

\footnotetext{
1 M. Heidegger, Bycie i czas, przeł. B. Baran, Warszawa 1994, s. 12.

2 E. Husserl, Idee czystej fenomenologii i fenomenologicznej filozofii, t. 1, przeł. D. Gierulanka, Warszawa 1967, s. 123.

3 W. Karpiński, Pamięć Włoch, Gdańsk 2002, s. 143-145.

4 Platon, Timaios, przeł. W. Witwicki, Warszawa 1960, s. 37 d.
} 
doskonałości okazuje się twórcza, gdyż daje możliwości osiągnięcia tego, co lepsze. Każda rzecz osiąga swój sens i wartość w relacji z człowiekiem.

W centrum pracy artystycznej znajduje się podmiot twórczy - ukształtowany za pośrednictwem podejmowanych działań i ich wytworów. Każde zjawisko kulturowe jest jak „monada, która odbija w sobie wszystko, sama się we wszystkim odbijając”. „Dziedzina kultury nie ma wewnętrznego terytorium, cała sytuuje się na granicach”. Dzieło sztuki jest uwikłane w różne dialektyczne związki ze swym twórcą i z tymi wszystkimi, dzięki którym w procesie odbioru konkretyzuje swoje istnienie estetyczne. Ryciny G. Piranesiego oprócz aspektów intencyjno-przedmiotowych pobudzają do głębszego namysłu nad rzeczywistością, czasem, egzystencją. Odsłaniają się one jako symbole, które stanowią asumpt do pogłębionej refleksji. Symbole, które są w łączności z konkretnymi wydarzeniami, historiami, a nawet dramatami.

Paul Ricœur w artykule Parole et symbole podkreślił, że symbol jest związany z całą głębią ludzkiego doświadczenia. Posiada fundamenty, które nadają mu taką trwałość i stabilność, iż można odnieść wrażenie, że nigdy nie umiera, a co najwyżej się przekształca ${ }^{7}$. W drugiej części pracy Finitude et culpabilité zatytułowanej La Symbolique du mal francuski filozof odniósł się do koncepcji podmiotu Immanuela Kanta i Edmunda Husserla, dowodząc, że człowiek buduje swoją tożsamość poprzez znaki i symbole (wielkich wytworów kulturowych) przechowywane w pamięci i wyobraźni. W szczególności symbole są drogą do odkrycia prawdy o człowieku ${ }^{8}$. Z kolei w książce De l'interprétation. Essai sur Freud P. Ricœur zaakcentował: „Symbol jest bowiem tą strukturą intencjonalną, która nie polega na relacji od sensu do rzeczy, lecz na architekturze sensu, na relacji od sensu do sensu, od sensu

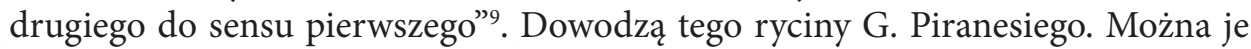
uporządkować według trzech kategorii: fantazje architektoniczne - Invenzioni caprici di carceri (1750, 1760), widoki współczesnego Rzymu - Vedute di Roma (od 1746) i rzymskie nokturny - Antichita romane $(1756)^{10}$. Prace włoskiego rytow-

${ }^{5}$ M. Bachtin, W strone filozofii czynu, przeł. B. Żyłko, Gdańsk 1997, s. 27.

${ }^{6}$ M. Bachtin, Problemy literatury i estetyki, przeł. W. Grajewski, Warszawa 1982, s. 26-27.

7 „Le symbole est lié. Le symbole a des racines. Le symbole plonge dans l'expériences ténébreuse de la Puissance. [...] Le symbolisme, parce qu'il plonge ses racines dans des constellations durables de la vie, du sentiment et du cosmos, a une stabilité incroyable, qui inclinerait à penser que le symbole ne meurt jamais, mais seulement se transforme”. P. Ricœur, Parole et symbole, „Revue des Sciences Religieuses" 1975, 49 (1-2), s. 157-161.

${ }^{8}$ P. Ricœur, Philosophie de la volanté. Finitude et culpabilité, t. 2, La Symbolique du mal, Paris 1963. Por. M. Jędraszewski, Zrozumieć siebie przez symbole, „Poznańskie Studia Teologiczne” 2002, 13, s. 271.

9 "C'est une structure intentionnelle qui ne consiste pas dans le rapport du sens à la chose, mais dans une architecture du sens, dans un rapport du sens au sens, du sens second au sens premier". P. Ricœur: De l'interprétation. Essai sur Freud, Paris 1965, s. 26-27.

${ }^{10}$ Należy wymienić przede wszystkim ryciny z cyklu Widoki Rzymu (Vedute di Roma): Widok wodospadu w Tivoli, 1740-1778, akwaforta; Fantazja z ruinami i posagiem Minerwy (frontispis do 
nika charakteryzują się wielowymiarowością, wzbudzają rozmaite nastroje i emocje. Należy je interpretować, uwzględniając nie tylko aspekty kulturowe i artystyczne, lecz także konteksty historyczne i metafizyczne. Ulya Vogt-Göknil w książce Carceri napisała, że przestrzenie G. Piranesiego nie są przestrzeniami zewnętrznymi ani wewnętrznymi, lecz mają strukturę prawdziwych Zwischenräume ${ }^{11}$. Termin ten należy rozumieć jako sferę pogranicza; tego, co obce i przyjazne, dostępne i niedostępne, skończone i nieskończone. Podstawowym elementem przedstawiania przestrzeni przez włoskiego rytownika było (za)stosowanie przeciwstawnych zabiegów architektonicznych. Wybór formy koła ma symbolizować wielkość i nieskończoność, a zarazem wzbudzać uczucie tajemniczości i stanowić rodzaj pewnego Labyrinth-Erlebnis ${ }^{12}$. Tajemnicze i melancholijne piękno płynące z rycin artysty uobecnia nieobecne, wyraża niewyrażalne, oddziałuje na duszę, wywołując wzruszenie i poczucie wzniosłości.

G. Piranesiemu przypisuje się również autorstwo rozprawy Della Magnificenza ed Architettura de’Romani, opublikowanej w 1761 roku w Rzymie, ze wstępem papieża Klemensa XIII ${ }^{13}$. G. Piranesi w rozprawie opisuje potęgę materialną i wielkie bogactwo kulturowe Italii:

drugiego tomu cyklu Widoki Rzymu), 1740 -1778, akwaforta; Ruiny term Antonina, 1740-1778, akwaforta. Zainteresowanie ruinami w sztuce zostało przejęte od malarzy z Północy, którzy w XVI wieku przybyli do Italii (wśród nich byli Joos van Cleve, Egbert van Heemskerck, Hieronymus Cock), stworzyli oni nowy rodzaj malarstwa nazywany „wedutą". Informacje na temat rycin pochodzą z Gabinetu Rycin Biblioteki Uniwersytetu Warszawskiego: Inw.zb.d. 10672; Inw.zb.d. 10678; Inw.zb.d. 10665; Inw.zb.d. 10696; Inw.zb.d. 10693.

${ }^{11}$ U. Vogt-Göknil, Carceri, Zürich 1958, s. 21. Por. L. Keller, Piranesi i mit spiralnych schodów, „Pamiętnik Literacki” 1976, 67, 1, s. 266.

${ }_{12}$ U. Vogt-Göknil, Carceri..., s. 23. Por. L. Keller, Piranesi i mit spiralnych schodów..., s. 266.

${ }_{13}$ Wśród licznych badaczy podejmujących temat twórczości włoskiego rytownika należy przypomnieć przede wszystkim: A.M. Hind, Giovanni Battista Piranesi; a critical study, with a list of his published works and detailed catalogues of the prisons and the views of Rome, London 1922; Giovanni Battista Piranesi: The Polemical Works, ed. J. Wilton-Ely, Farnborough 1972 (włoskie wydanie 1973); N. Penny, Piranesi, London 1988; J. Wilton-Ely, J. Connors, Piranesi Architetto, Rome 1922; J. Wilton-Ely, The Mind and Art Giovanni Battista Piranesi, London 1978; Idem, Piranesi as Architect and Designer, New Haven 1993; Idem, Piranesi, Milan 1994; Idem, Giovanni Battista Piranesi: The Complete Etchings - an Illustrated Catalogue, San Francisco 1994; Idem, The Voices of the Imagination: Creative and Critical Responses to Piranesi from his Contemporaries and from Posterity, Los Angeles 1995; Idem, Piranesi, Paestum and Soane, London 2002; L. Ficacci, Piranesi. The Complete Etching, Köln 2000; G.B. Piranesi, Observations on the letter of Monsieur Mariette with Opinions on Architecture and a Preface to a New Treatise on the Introduction and Progress of the Fine Arts in Europe in Ancient Times, trans. by C. Beamish, D. Britt, introd. by J. Wilton-Ely, Los Angeles 2002; Piranesi as Designer, eds. J. Wilton-Ely et al., New York 2007; M.H. Hyde, Piranesi's lost words, London 2015; E. Szpakowska-Loranc, L'espace Piranesien, „Czasopismo Techniczne” 2015, Architektura, z. 10-A (16), s. 41-50; D. Klemm, Piranesi. Carceri, Berlin 2016; R. Langenbach, Rome Was!: The Eternal City, from Piranesi to the Present, New York 2019. 
A gran tempo fra me pensando, perchè mai, non essendovi chi neghi, aver il Popolo Romano fiorito nelle Arti della guerra, e della pace, tolgaglisi poi da taluno la lode della magnificenza, m' è sembrato, ciò derivare da una certa soverchia facilità, e precipitanza nel giudicare, quanto in oggi contraria alla riputazion de' Romani, altrettanto nociva sempre alla verità. [...] Poichè non eran mica poveri, come forse talun pensa, gl' Italiani, essendo abitatori d' un paese de' più felici, e di più provvedendo colle loro arti ed industria, in sì fatta guisa ai loro privati bisogni, e al decoro della repubblica, che, secondo la condizione di que' tempi, non la cedevano a verun' altra Nazione. [...] Ed a qual fine Cicerone, Plinio, Plutarco, ed altri non pochi avrebbero commendata la parsimonia de' Romani, che ne' tempi anteriori se n' erano compiaciuti, se fossero stati costretti ad esser parchi, non per elezione, ma per iscarsezza di beni di fortuna? ${ }^{14}$

G. Piranesi przedstawił Włochy jako wyjątkową przestrzeń artystyczną i egzystencjalną, gdzie sztuka i życie nawzajem się przenikają. Wskazał na zmediatyzowany charakter przeszłości - między podmiotem a przedmiotem, między artystą a zdarzeniami minionymi, między teraźniejszością a przyszłością umieszczone są wytwory przeszłości: budowle architektoniczne, przedmioty, pisma, inskrypcje. Przeszłość pozostawia dobra kultury materialnej i duchowej, które należy analizować, reinterpretować i odtwarzać. Jak zauważył W. Karpiński, G. Piranesi za swoje powołanie uważał obronę przeszłości, tradycji, którą on tylko zdoła ocalić. Przedstawił swoją wizję Rzymu, nie podążając za współczesnymi mu kierunkami artystycznymi. Odkrył na nowo piękną i wspaniałą przeszłość Wiecznego Miasta.

Lucilio Vanini w Essay on liberty and necessity podkreślił, że najważniejszym zadaniem człowieka jest odkrycie kultury, czyli zrozumienie, że najwyższą wartością jest świat artefaktów wytworzonych przez człowieka i ta wartość określa sens życia jednostki i społeczeństwa ${ }^{15}$. Jednym z pierwszych autorów tej myśli był żyjący w XV wieku Giannozzo Manetti, twórca De dignitate et excellentia hominis, który widział w odkrywaniu kultury godność człowieka. To człowiek jest autorem projektów architektonicznych, budowli, dzieł artystycznych: obrazów, rzeźb, utworów literackich. Interesującym dopełnieniem tezy G. Manettiego jest zawarta w De gl'heroici furori myśl Giordana Bruna, że o wartości kultury stanowi różnorodność umysłów ludzkich $^{16}$. O policentrycznej filozofii kultury pisało wielu filozofów i teoretyków

\footnotetext{
${ }^{14}$ G. Piranesi, Della Magnificenza ed Architettura de'Romani, Roma 1761, s. 13.

15 A. Nowicki, Centralne kategorie filozofii Vaniniego, Warszawa 1970, s. 11. Por. Idem, Filozofia włoskiego odrodzenia, Warszawa 1967, s. 20-23, 71-72.

16 G. Bruno, G. Gentile, G. Aguilecchia, Dialoghi italiani: dialoghi metafisici e dialoghi morali, Firenze 1958, s. 957-959.
} 
kultury, m.in.: Eugenio Garin, Antonio Corsano, Bruno Nardi ${ }^{17}$. Warto tu przywołać jeszcze myśl niemieckiego filozofa Ernsta Blocha: „To, co już rzeczywiste, jest otoczone morzem możliwości i stale z tego morza wyłania się jakiś nowy fragment rzeczywistości"18. Dane zjawisko, obiekt, przedmiot oprócz dosłownego odczytania, zrozumienia wymaga od odbiorcy twórczej interpretacji. Tak postępował G. Piranesi, kierował się zawsze tym samym pragnieniem - zgłębić minioną wielkość, by nie zatracić dorobku pokoleń i przechowywanych w nim wartości. Na szczególną uwagę zasługuje jego rycina Veduta dell'Anfiteatro Flavio detto il Colosseo (1757). Przedstawia ona jedną z najsłynniejszych budowli świata, największy obiekt w Rzymie, który przez wieki inspirował artystów. Pod ryciną włoski architekt umieścił w dwunastu punktach opis Koloseum:

A. Archi del prim' Ordine dell' Anfiteatro, pe' quali il popolo ascendeva ai gradi degli Spettacoli.

B. Recinti moderni.

C. Numeri incisi negli stessi archi, forse per segno di chi desiderava d'esser rinvenuto, fra la moltitudine degli Spettatori.

D. Arco senza numero, sopra cui era immarginato il ponte che dalle fabbriche Cesaree dell' Esquilino dava l'ingresso nell'Anfito.

E. Parte dell'Anfit ${ }^{\circ}$. deturpata dagl' Incendj.

F. Archi del secondo e terz'ordine anticamente intrachiusi da'parapetti déquali vi restano alcuni segni e residui.

G. Mensole su cui posavano le antenne di mettalo, che passando per la cornice foftenevano la gran tenda.

H. Architrave interroto dalle antenne, nelle quali era impressa la parte interrotta del medesimo.

${ }^{17}$ Eugenio Garin, autor takich prac, jak: L'Umanesimo italiano, Laterza 1952; Medioevo e Rinascimento, Laterza 1954; Cronache di filosofia italiana, Laterza 1955; L'educazione in Europa 1400-1600, Laterza 1957; La filosofia come sapere storico, Laterza 1959; La cultura filosofica del Rinascimento italiano, Laterza 1960; La cultura italiana tra Ottocento e Novecento, Laterza 1962; Scienza e vita civile nel Rinascimento italiano, New York 1965; Storia della filosofia italiana (tree volumi), Amsterdam-New York 1966; Dal Rinascimento all'Illuminismo, New York 1970; Intellettuali italiani del XX secolo, Roma 1974; Rinascite e rivoluzioni, Laterza 1975; Tra due secoli, London 1983; Vita e opere di Cartesio, Laterza 1984; Gli editori italiani tra Ottocento e Novecento, Laterza 1991. Antonio Corsano, autor dzieł: Il pensiero politico di G.B. Vico, Il Solco 1923; Il Pomponazzi nella storia religiosa del Rinascimento, Laterza 1935; Umanesimo e religione in G.B. Vico, Laterza 1935; Il pensiero religioso italiano dall'umanesimo al giurisdizionalismo, Laterza 1937; Studi sul pensiero del tardo Rinascimento, Sansoni 1958; Bayle, Leibniz e la storia, Guida 1971; Opere scelte, 6 volumi, Congedo 1999. Bruno Nardi, autor m.in.: Saggi e note di critica dantesca, Milano-Napoli 1966; Idem, Saggi di filosofia dantesca, Firenze 1967; Studi di filosofia medievale, Roma 1979; Dante e la cultura medievale, introduzione di T. Gregory, Laterza 1985.

${ }^{18}$ E. Bloch, Subjekt-Objekt. Erläuterungen zu Hegel, Berlin 1952, s. 475. 
I. Radici del monte. Esquilino.

K. Arco di Costantino.

L. Monte Celio.

M. Principio della via si S. Gio. Laterano ${ }^{19}$.

Krótkie przypomnienie historii powstania Koloseum i interpretacja opisu stworzonego przez G. Piranesiego jest w tym miejscu kluczowa.

W 71 roku naszej ery imperator Wespazjan (Caesar Vespasianus Augustus) zainicjował budowę Amfiteatru Flawiuszów (Amphitheatrum Flavium) na terenie Złotego Domu (Domus Aurea) Nerona, między wzgórzami Wiminału (Collis Viminalis), Celiusa (Mons Caelius) i Eskwilinu (Mons Esquilinus) ${ }^{20}$. W Chronologusie z 354 roku można przeczytać, że cesarz rzymski otworzył Amfiteatr, kiedy ukończone były trzy gradusy, za czasów Tytusa dobudowano dwa następne, a za Domicjana dokończono go usque ad clypea, to znaczy do brązowych tarcz znajdujących się na drugim polu attyki (punkty $\mathrm{I}-\mathrm{M}$ ) ${ }^{21}$. Na trzystopniowym stylobacie, który chroni portyk przed wodą, wybudowano na planie elipsy trzy ogromne kondygnacje arkad z trawertynu zwieńczone wysoką attyką. Każda z nich liczyła osiemdziesiąt łuków arkadowych (punkty A i F) 22. Przy głównym wejściu znajdowały się marmurowe kolumny, nad którymi wznosiły się kwadrygi. Każdy łuk miał przyporządkowaną cyfrę. Lico ściany attyki podzielono na prostokąty pilastrami korynckimi, z których co drugi ma prostokątne okno na przemian z brązowymi złoconymi tarczami (punkt C). Ostateczne zwieńczenie tworzył wystający gzyms wsparty na (240) konsolach służących do przymocowania masztów, na których rozciągano velarium lnianą zasłonę chroniącą przed promieniami słonecznymi (punkt G). Przestrzeń wokół budowli na siedemnastu i pół metra szerokości wyłożono trawertynem, jej granicę wyznaczały kamienne słupy (punkt $\mathrm{H})^{23}$.

Tertulian w III wieku napisał o Koloseum: „Pluribus eniam et asperioribus numinibus amphiteatrum consecratur, quam Capitolium omnium daemunum templum est" ${ }^{24}$. W Amfiteatrze urządzano walki gladiatorów, polowania na

${ }^{19}$ Opis znajduje się pod ryciną G. Piranesiego: G.B. Piranessi, Veduta dell'Anfiteatro Flavio detto il Colosseo, 1757.

${ }^{20}$ Niektórzy badacze przyjmują inne daty powstania: P. Quenncl (w książce The Colosseum) przyjmuje 72 rok; R. Luciani (Il Colosseo, Milano 1993) podaje datę 71-72, autor ten akceptuje propozycję G. Lugliego (Roma antica. Il centro monumentale, Roma 1965). Por. M. Wrześniak, Koloseum: od rzymskiego amfiteatru do chrześcijańskiej świątyni, „Saeculum Christianum: pismo historyczno-społeczne” 2000, 7/1, s. 199-206.

${ }^{21}$ R. Luciani, Il Colosseo..., s. 55; A.N. Modona, Gli edifici teatrali greci e romani. Teatri, odei, anfiteatri, circhi, Firenze 1961, s. 261; M. Wrześniak, Koloseum..., s. 199-206.

${ }_{22}$ A.N. Modona, Gli edifici teatrali greci e romani..., s. 261. Por. M. Wrześniak, Koloseum..., s. $199-206$.

${ }^{23}$ G. Lugli, Il centro monumentale, Roma 1965, s. 325-330.

${ }^{24}$ R. Luciani, Il Colosseo, Milano-Novara 2000, s. 193. 
dzikie zwierzęta, czasami przedstawiano inscenizacje mitów lub ważnych wydarzeń historycznych. Od 1774 roku za sprawą papieża Benedykta XIV Koloseum stało się miejscem upamiętniającym męczenników chrześcijańskich ${ }^{25}$. Była to ziemia naznaczona krwią; sferę profanum przenikało sacrum, dlatego to tu postanowiono wystawiać misteria czy przedstawienia o tematyce religijnej, o czym w interesujący sposób piszą badacze w książce Colosseo:

Il dramma sacro della Passione di Cristo (martirio prototipico) proponeva, con ricco e suggestivo apparato di congegni e macchine sceniche, „quadri viventi" narrati in rima con accompagnamento musicale, in un allestimento che conferiva una potente aura di sacralizzazione al monumento antico, percepito come ineguagliabile scenografia classica secondo i gusti e le pratiche del teatro rinascimentale ${ }^{26}$.

Amfiteatr Flawiuszów był miejscem rozgrywającego się dramatu człowieka. To scena, na której toczyła się walka między życiem i śmiercią, tu odsłaniała się prawda o świecie, o drugim człowieku. Na tej scenie człowiek stał w obliczu walki o swoje "Ja", o obronę swej tożsamości w zmiennym strumieniu zdarzeń.

Dlatego tak ważnym obiektem dla G. Piranesiego było Koloseum, wyjątkowe miejsce doświadczania czasu, poznawania historii, odkrywania siebie. Używając sformułowania Pierre’a Nory, jest to „miejsce pamięci”27, „miejsce wspomnien”,

${ }^{25}$ M. Wrześniak, Koloseum..., s. 199-219.

${ }^{26}$ Colosseo, eds. R. Rea, S. Romano, R. Santangeli Valenzani, Roma 2017, s. 51. Por. F. Cruciani, Teatro nel Rinascimento Roma 1450-1550, Rome 1983, s. 210-219, 263-270, 470-473, 522-524; A. Sinopoli, F.T. Di Pasquale, Collapse analysis of Colosseum arcades by seismic events, "ARCH'07-5th International Conference on Arch Bridges” 2007, s. 459-466; M. Como, U. Ianniruberto, M. Imbimbo, Limit analysis of the structures of Colosseum, w: International Conference on Historical Constructions, eds. P.B. Lourenço, P. Roca, Guimarães 2001, s. 665-673. Por. M. Wrześniak, Koloseum..., s. 209.

${ }^{27}$ Pierre Nora, francuski historyk, członek trzeciego pokolenia École des Annales. Najważniejsze publikacje: Ernest Lavisse: son rôle dans la formation du sentiment national, „Revue historique” 1962; Vincent Auriol. Journal du Septennat 1947-1954 (1970-1979); Faire de l'histoire, Paris 1973; Essais d'ego-histoire, Paris 1987; Les Lieux de mémoire, Paris 1984-1992, abridged translation, Realms of Memory, New York 1996-1998; Rethinking France: Les Lieux de mémoire, vol. 1, The State, Chicago 1999; Rethinking France: Les Lieux de mémoire, vol. 2, Space, Chicago 2006; Rethinking France: Les Lieux de mémoire, vol. 3, Legacies, Chicago 2009; Rethinking France: Les Lieux de mémoire, vol. 4, Histories and Memories, Chicago 2010. Warto jeszcze przypomnieć najważniejsze wyróżnienia P. Nory: Grand officier de la Légion d'honneur; Officier de l'ordre national du Mérite; Commandeur des Arts et des Lettres. Informacje pochodzą z: Académie française 23, quai de Conti 75270 Paris. Por. http://www.academie-francaise.fr/les-immortels/pierre-nora?fauteuil=27\&elect ion=07-06-2001 (dostęp: 8.12.2020). 
„miejsce, w którym się wspomina”28. Francuski historyk skonstatował, że pamięć może spełniać funkcje społeczne, kulturowe i polityczne, w zależności od tego, jakie grupy, instytucje i autorytety odgrywają rolę przewodników i ją aktywizują. W tym przypadku przewodnikiem stał się G. Piranesi: „Kto widział jego ryciny, ten i dzisiaj patrzeć będzie na zwaliska miasta oczami Piranesiego" ${ }^{29}$. Włoski rytownik w swych pracach tak poprowadził linie przy użyciu techniki silhouette i lawowania, aby odbiorca nie tylko zobaczył odtworzoną przestrzeń, lecz także aktywizując swoją wyobraźnię, znalazł się we wnętrzu przedstawionego świata; aby zobaczył siebie jako aktora uczestniczącego w dramacie świata. Józef Tischner w książce Filozofia dramatu napisał:

Być istotą dramatyczną to znaczy: przeżywać dany czas, mając wokół siebie innych ludzi, ziemię jako scenę pod stopami. Dramat nie jest zatem pewną obojętną aksjologicznie konstrukcją życia i kultury, jest walką o „być” lub „nie być" człowieka ${ }^{30}$.

Można dodać: jest walką o jak najpiękniejszy rozwój etyczny swojego „Ja”.

Koloseum dla G. Piranesiego jest miejscem, w którym zacierają się granice między życiem a sztuką. To przestrzeń spotkania przeszłości z teraźniejszością, człowieka z człowiekiem, artysty z widzem, aktora $\mathrm{z}$ aktorem. To również sfera przeżywanych przez ludzi idei, wartości, tego, co znajduje się ponad uczestnikami dramatu. Każdy artefakt jest czymś materialnym i jednocześnie zawiera w sobie ideę, powoduje to, że staje się „innym”. Gdzie poszukiwać w Koloseum tego „innego”? Na ostatniej kondygnacji, tam, gdzie jest ono okaleczone ${ }^{31}$, skrywa się idea tego obiektu.

28 P. Nora, Mémoire collective, w: Faire de l'histoire, sous la dir. de J. Le Goff, P. Nora, Paris 1974, s. 401. Por. A. Szpociński, Miejsca pamięci (lieux de mémoire), „Teksty Drugie” 2008, 4, s. 11-14.

${ }^{29}$ W. Karpiński, Pamięć Włoch..., s. 142.

${ }^{30}$ J. Tischner, Filozofia dramatu, Kraków 1998, s. 8-10. Por. Idem, Myślenie według wartości, Kraków 1982; Idem, O człowieku. Wybór pism filozoficznych, oprac. A. Bobko, Wrocław 2003.

${ }^{31} \mathrm{Na}$ temat brakującej części Koloseum piszą A. Sinopoli i F.T. Di Pasquale: „For the Colosseum this history is particularly complex because of the effect of fires, the action of earthquakes, the despoliation of the materials used for other buildings and the geotechnical features of the foundation soil (F. Bozzano, R. Funiciello, F. Marra, A. Rovelli, G. Valentini, Il sottosuolo dell'area dell'Anfiteatro Flavio di Roma. Geologia Applicata e Idrogeologia 30. Part I, Bari 1995). These events offer an aleatory picture that makes it difficult to reach sure conclusions on the way of collapse of the missing parts. In spite of this, the documents on the seismic history of the monument induce to believe that earthquakes were the most credible cause of failure of the missing parts. In fact, the catalogue of the historical earthquakes (E. Boschi, E. Guidoboni, G. Ferrari, D. Margotti, G. Valensise, P. Gasperini, Catalogue of Strong Italian Earthquakes from 461 B.C. to 1997. I) occurred in the country area surrounding Rome, and in particular those that determined serious damages in many Roman buildings, supports our assumption. Among these numerous seismic events, the earthquake of 1349 seems to be the most probable that, also for its intensity, determined the collapse of some arcades of the Colosseum, as tested by Petrarca in a letter of the same year: cecidit 
Od widza wymaga to głębokiego namysłu nad sferą metafizyczną, P. Ricœur taką postawę określa transcendentalną dedukcją symbolu ${ }^{32}$. Włoski rytownik domagał się od odbiorcy swego dzieła przede wszystkim trzech czynności: zachowania rozbitego, rekonstrukcji rozbitego i podniesienia go na wyższy poziom, ku „doskonałemu dopełnieniu”. Rozpad jest nieodzownym warunkiem drogi, która prowadzi znów do doskonałości. Doskonałość jest stanem, który nie może zaistnieć, jak napisał Georg Wilhelm Hegel, lecz musi być zniesiony ${ }^{33}$. To znaczy, że doskonałość zawiera w sobie moment sprzeczności, samozniszczenia? Doskonałość jest możliwa w momencie, kiedy wzniesiemy się na wyższy poziom. Rycina G. Piranesiego wskazuje na porządek aposterioryczny, na konkretny obiekt, wydarzenie historyczne, a zarazem jest przejściem z poziomu realnego na poziom transcendentalny. Tajemniczość i wielkość sztuki włoskiego artysty polega na dążeniu do Absolutu i zarazem byciu wiernym wobec świata. Jego ryciny często przedstawiały zapomniane miejsca, ruiny, przez które mówił o sprawach czasu, trwania, wieczności.

Koło, na którym wznosi się Koloseum, można odczytać jako koło hermeneutyczne ${ }^{34}$. Mam tu na myśli hermeneutykę nie jako sztukę interpretacji tekstów, lecz teorię rozumienia sposobu doświadczania świata przez człowieka. W budowaniu tej teorii ważną rolę odegrał Martin Heidegger, który podkreślił w swoich badaniach, że świat i człowiek to splot uporządkowanych sensów ${ }^{35}$. Człowiek jest wpisany w koło hermeneutyczne, to znaczy, że nosi w sobie pewne przedrozumienie, które wyznacza kierunek odczytywania sensów, ulega on zmianom i ciągłemu wzbogacaniu przez nowe doświadczenia i poznania. Metoda hermeneutyczna jest niezbędna, aby zrozumieć człowieka uwikłanego w czas i konkretne uwarunkowania kulturowo-społeczne. P. Ricœur w pracy L'Homme faillible podkreślał: „Charakterystyka [...] [człowieka - B.T.] d’être-intermédiare polega dokładnie na tym, że jego akt istnienia jest właśnie aktem dokonywania zapośredniczeń między wszystkimi modalnościami i wszystkimi poziomami rzeczywistości poza nim i w nim samym" ${ }^{36}$.

Podmiot jest coraz bliżej w odkryciu swojego „Ja”, przechodząc na coraz wyższy poziom poznawanych sensów: od życia do sztuki; od tego, co materialne, do tego, co

aedificiorum veterum neglecta civibus, stupenda peregrinis mole”. A. Sinopoli, F.T. Di Pasquale, Collapse analysis of Colosseum arcades by seismic events..., s. 459.

${ }^{32}$ P. Ricœur, Symbol daje do myślenia, w: Idem, Egzystencja i hermeneutyka, rozprawy o metodzie, przeł. S. Cichowicz et al., Warszawa 1985, s. 335.

${ }_{33}$ G.W. Hegel, Wykłady o estetyce, t. 1, przeł. J. Grabowski, A. Landman, Warszawa 1964, s. $124-125$.

${ }^{34}$ A. Warmbier, Tożsamość, narracja i hermeneutyka siebie. Paula Ricoura filozofia człowieka, Kraków 2018, s. 71-179.

${ }^{35}$ M. Heidegger, Co znaczy myśleć, przeł. J. Mizera, J. Tischner, w: Filozofia współczesna, t. 1, red. Z. Kuderowicz, Warszawa 1983, s. 229.

${ }^{36}$ P. Ricœur, Philisophie de la volanté. Finitude et culpabilité, t. 2, L'Homme faillible, Paris 1960, s. 23. 
duchowe; od tego, co ziemskie, do tego, co metafizyczne. Jak napisał W. Karpiński w książce Pamięć Włoch, ryciny włoskiego rytownika są:

metafizyką przestrzeni, pytaniem o miejsce człowieka w świecie. Zostaliśmy rzuceni w przestrzeń, nad nami milczące obojętne niebo - zdaje się wołać Piranesi. [...] wspina się ciągle po niekończących się schodach wyobraźni. W tym jego siła. A czerpał ją z anteuszowego kontaktu z ziemią, $\mathrm{z}$ czasem, z przeszłością. Oto sens zafascynowania ruinami ${ }^{37}$.

G. Piranesi wskazuje na dwie postawy: retrospektywną, która dotyczy rozumienia tego, co minione, i prospektywną odnoszącą się do tego, co przyszłe. Człowiek może budować swoją tożsamość, kiedy nie zapomina o przeszłości. P. Ricœur w książce Drogi rozpoznania. Wykłady Instytutu Nauk o Człowieku konstatował, że rozpoznać wspomnienie to je odnaleźć. Odnaleźć coś to znaczy mieć do tego dostęp. Przeszłość pozostaje w ścisłej relacji z teraźniejszością. Taki jest ukryty sens zachowanych wspomnień z przeszłości ${ }^{38}$. Wartości objawiają się na przestrzeni dziejów, dlatego tak ważne jest zachowywanie wspomnień i odczytywanie znaków i symboli przeszłości. Oprócz sfery rzeczywistej istnieje świat transcendentalny. Człowiek jest egzystencją, odnosi się do świata, odkrywa go, tworzy i interpretuje, ale również odkrywa i tworzy samego siebie: „Jest bytem per se, który odnosi się do wartości będących poza nim - tworzy siebie jako wartość, wartość szczególną, której na imię »Ja«"39.

Rycina Veduta dell'Anfiteatro Flavio detto il Colosseo Giovanniego Battisty Piranesiego przypomina o symbolicznym miejscu, jakim jest Koloseum, w którym rozgrywa się dramat człowieka. Dramat walki o „być” lub „nie być”, walki o wartości - takie jak: wolność, prawda, dobro - po to, aby życie było piękne.

Bibliografia

Bachtin M., Problemy literatury i estetyki, przeł. W. Grajewski, Warszawa 1982.

Bachtin M., W stronę filozofii czynu, przeł. B. Żyłko, Gdańsk 1997.

Bloch E., Subjekt-Objekt. Erläuterungen zu Hegel, Berlin 1952.

Bruno G., Gentile G., Aguilecchia G., Dialoghi italiani: dialoghi metafisici e dialoghi morali, Firenze 1958.

\footnotetext{
${ }^{37}$ W. Karpiński, Pamięć Włoch..., s. 150.

${ }_{38}$ P. Ricoeur, Drogi rozpoznania. Wykłady Instytutu Nauk o Człowieku, przeł. J. Margański, Kraków 2004, s. 118.

${ }^{39}$ J. Tischner, Etyka wartości i nadziei, w: D. Von Hildebrandt, J.A. Kłoczowski, J. Paściak, Wobec wartości, Poznań 1982, s. 55.
} 
Colosseo, eds. R. Rea, S. Romano, R. Santangeli Valenzani, Roma 2017.

Como M., Ianniruberto U., Imbimbo M., Limit analysis of the structures of Colosseum, w: International Conference on Historical Constructions, eds. P.B. Lourenço, P. Roca, Guimarães 2001, s. 665-673.

Cruciani F., Teatro nel Rinascimento Roma 1450-1550, Roma 1983.

Ficacci L., Piranesi. The Complete Ething, Köln 2000.

Hegel G.W., Wykłady o estetyce, t. 1, przeł. J. Grabowski, A. Landman, Warszawa 1964.

Heidegger M., Co znaczy myśleć, przeł. J. Mizera, J. Tischner, w: Filozofia wspótczesna, t. 1, red. Z. Kuderowicz, Warszawa 1983, s. 229.

Heidegger M., Źródła dzieła sztuki, przeł. J. Mizera, w: M. Heidegger, Drogi lasu, przeł. J. Gierasimiuk et al., Warszawa 1997, s. 9-58.

Hind A.M., Giovanni Battista Piranesi; a critical study, with a list of his published works and detailed catalogues of the prisons and the views of Rome, London 1922.

Husserl E., Idee czystej fenomenologii i fenomenologicznej filozofii, t. 1, przeł. D. Gierulanka, Warszawa 1967, s. 123.

Hyde M.H., Piranesi's lost words, London 2015.

Giovanni Battista Piranesi: The Polemical Works, ed. J. Wilton-Ely, Farnborough 1972 (wydanie włoskie - 1973).

Jędraszewski M., Zrozumieć siebie przez symbole, „Poznańskie Studia Teologiczne” 2002, 13, s. 269— 293.

Karpiński W., Pamięć Włoch, Gdańsk 2002.

Keller L., Piranèse et les romantiques français. Le mythe des escaliers en spirale, Paris 1966.

Keller L., Piranesi i mit spiralnych schodów, „Pamiętnik Literacki” 1976, 67, 1, s. 257-277.

Klemm D., Piranesi. Carceri, Berlin 2016.

Kopaliński W., Słownik symboli, Warszawa 1990.

Langenbach R., Rome Was!: The Eternal City, from Piranesi to the Present, New York 2019.

Luciani R., Il Colosseo, Milano 1993.

Luciani R., Il Colosseo, Milano-Novara 2000.

Lugli G., Roma autica. Il centro monumentale, Roma 1965.

Modona Neppi A., Gli edifici teatrali greci e romani. Teatri, odei, anfiteatri, circhi, Firenze 1961.

Musioł A., Ernst Cassirer neokantystą? Między forma symboliczna jako istota kultury a filozofią Immanuela Kanta, w: Filozofia Kanta i jej recepcja, red. D. Bęben, A.J. Noras, Katowice 2011, s. 199-215.

Nora P., Mémoire collective, w: Faire de l'histoire, sous la dir. de J. Le Goff, P. Nora, Paris 1974, s. XIX-XXI, 401.

Nowicki A., Filozofia włoskiego odrodzenia, Warszawa 1967.

Nowicki A., Centralne kategorie filozofii Vaniniego, Warszawa 1970.

Penny N., Piranesi, London 1988.

Piranesi G.B., Observations on the letter of Monsieur Mariette with Opinions on Architecture, and a Preface to a New Treatise on the Introduction and Progress of the Fine Arts in Europe in Ancient Times, trans. by C. Beamish, D. Britt, introd. by J. Wilton-Ely, Los Angeles 2002.

Piranesi as Designer, eds. J. Wilton-Ely et al., New York 2007.

Poulet G., Piranèse et les romantiques français, „Cahiers de l'Association internationale des études françaises" 1966, 18, s. 179-188.

Ricœur P., Philisophie de la volanté. Finitude et culpabilité, t. 1, L'Homme faillible, Paris 1960.

Ricœur P., Philosophie de la volanté. Finitude et culpabilité, t. 2, La Symbolique du mal, Paris 1963.

Ricœur P., De I'interprétation. Essai sur Freud, Paris 1965.

Ricour P., Parole et symbole, „Revue des Sciences Religieuses” 1975, 49 (1-2), s. 142-161.

Ricœur P., Symbol daje do myślenia, w: Idem, Egzystencja i hermeneutyka, rozprawy o metodzie, przeł.

S. Cichowicz et al., Warszawa 1985, s. 58. 
Ricœur P., Drogi rozpoznania. Wykłady Instytutu Nauk o Człowieku, przeł. J. Margański, Kraków 2004.

Rousset J., La Littérature de lâge baroque en France, Paris 1954.

Sharp D., Leksykon pojęć i idei C.G. Junga, przeł. J. Prokopiuk, Wrocław 1998.

Sinopoli A., Pasquale F.T. Di., Collapse analysis of Colosseum arcades by seismic events, „ARCH'07-5th International Conference on Arch Bridges" 2007, s. 459-466.

Stróżewski W., Wokót piękna. Szkice z estetyki, Kraków 2002.

Szpakowska-Loranc E., L'espace Piranesien, „Czasopismo Techniczne” 2015, Architektura, z. 10-A (16), s. 41-50.

Szpociński A., Miejsca pamięci (lieux de mémoire), „Teksty Drugie” 2008, 4, s. 11-20.

Sztuka i społeczeństwo, t. 2, Kreatywne funkcje sztuki, red. A. Kuczyńska, Warszawa 1976.

Tischner J., Etyka wartości i nadziei, w: D. Von Hildebrandt, J.A. Kłoczowski, J. Paściak, Wobec wartości, Poznań 1982, s. 51-148.

Tischner J., Myślenie według wartości, Kraków 1982.

Tischner J., Filozofia dramatu, Kraków 1998.

Tischner J., O człowieku. Wybór pism filozoficznych, oprac. A. Bobko, Wrocław 2003.

Vogt-Göknil U., Carceri, Zürich 1958.

Warmbier A., Tożsamość, narracja i hermeneutyka siebie. Paula Ricoeura filozofia człowieka, Kraków 2018.

Wilton-Ely J., The Mind and Art Giovanni Battista Piranesi, London 1978.

Wilton-Ely J., Piranesi as Architect and Designer, New Haven 1993.

Wilton-Ely J., Piranesi, Milan 1994.

Wilton-Ely J., Giovanni Battista Piranesi: The Complete Etchings - an Illustrated Catalogue, San Francisco 1994.

Wilton-Ely J., The Voices of the Imagination: Creative and Critical Responses to Piranesi from his Contemporaries and from Posterity, Los Angeles 1995.

Wilton-Ely J., Piranesi, Paestum and Soane, London 2002.

Wilton-Ely J., Connors J., Piranesi Architetto, Rome 1992.

Wrześniak M., Koloseum: od rzymskiego amfiteatru do chrześcijańskiej świątyni, „Saeculum Christianum: pismo historyczno-społeczne" 2000, 7/1, s. 199-219.

Yates F., Sztuka pamięci, przeł. W. Radwański, posł. L. Szczucki, Warszawa 1977.

Barbara Trygar

Veduta dell'Anfiteatro Flavio detto il Colosseo of Giovanni Battista Piranesi

Summary

In this article, Barbara Trygar analyses Giovanni Battista Piranesi's The Veduta dell'Anfiteatro Flavio drawing detto il Colosseo. The Colosseum is one of world's greatest buildings and for centuries it has inspired artists all over the world. This symbolic place reminds man about the drama of life: the fight between "to be" and "not to be" and the struggle for the values of freedom, truth, and the good. The drawing (engraving) by the Italian printmaker is a provoking reflection on the axiological and metaphysical dimensions of human life.

Key words: Rome, the Colosseum, the past, a "place of memory", Giovanni Battista Piranesi, engraving, ideas, values 